\title{
Motivating Action through Fostering Climate Change Hope and Concern and Avoiding Despair among Adolescents
}

\author{
Kathryn Stevenson ${ }^{\dagger, *}$ and Nils Peterson ${ }^{\dagger}$ \\ Received: 2 December 2015; Accepted: 18 December 2015; Published: 23 December 2015 \\ Academic Editor: Ian Thomas \\ Fisheries, Wildlife \& Conservation Biology Program, Department of Forestry \& Environmental Resources, \\ North Carolina State University, Raleigh, NC 27695, USA; nils_peterson@ncsu.edu \\ * Correspondence: kathryn_stevenson@ncsu.edu; Tel.: +1-919-515-2739 \\ + These authors contributed equally to this work.
}

\begin{abstract}
Efforts to build climate change concern seem warranted to overcome apathy and promote action. However, research suggests that these efforts can backfire by breeding despair, denial and inaction. This may be especially true among younger audiences, as despair is highest among those who view climate challenges as out of their control, and children generally have lower perceived and actual control than adults in political and personal arenas. Though many studies have documented feelings of despair and sadness among younger audiences, few have explored how climate change hope may counteract despair and encourage productive responses to climate change concern. This study examined how climate change hope, despair, and concern predict pro-environmental behavior with a quantitative survey of a random sample of middle school students in North Carolina, USA $(\mathrm{n}=1486)$. We did not find an interaction between climate change hope and concern or despair, but instead found climate change hope and concern independently and positively related to behavior and despair negatively related to behavior. These results suggest that climate change concern among K-12 audiences may be an important antecedent to behavior which does not dampen the positive impacts of hope. Further, rather than mitigating the negative effects of climate change despair, hope may be an independent predecessor to behavior. Students at Title I (a measure of low socioeconomic status) schools were less likely to engage in pro-environmental behaviors, suggesting climate literacy efforts should target schools with lower levels of socioeconomic status specifically.
\end{abstract}

Keywords: climate literacy; concern; hope; climate action; pro-environmental behavior

\section{Introduction}

Efforts to promote proactive responses to climate change typically start with education under the premise that climate change knowledge leads to climate change concern, which in turn encourages behavior change. This logic is supported by several studies suggesting that climate change knowledge is positively correlated with climate change concern [1-4] and others that have linked climate change concern to both individual and collective climate action [3,5]. In fact, one US study found that concern was the most important predictor of support for national policies aimed at addressing climate change [6].

Although building climate change concern may encourage both individual and collective climate action, some research suggests that efforts to build concern can breed despair or denial. Affective images can build climate change concern [7], and in particular, fear-based messaging can be highly effective at promoting behavior change [8,9]. This may be why fear-based messaging (e.g., the movie The Day After Tomorrow, images of the Earth on fire) has been widely used in attempts to 
build climate concern [9-11]. However, fear-based messaging can backfire when individuals perceive low levels of agency or control [8]. The complexity and uncertainty associated with climate change coupled with the lack of immediate, tangible connections between actions (e.g., driving less) and impacts (e.g., collective emission reductions slowing or reducing global warming) may explain why climate communication efforts utilizing fear-based messaging may breed inactivity instead of action [9]. Because individuals perceive climate change as out of their control or fail to see how they can make a meaningful difference, they may cope with feelings of fear by denying that there is anything to be concerned about or conclude that attempts to build concern are manipulation instead of education [6,8,9]. The challenge for climate communicators is to convey the reality of threats associated with climate change while fostering a sense that something can be done and that individuals and societies can make a difference [6].

Understanding how to effectively build climate concern in ways that lead to action may be particularly important among younger audiences, both because climate change is projected to be a defining issue of their generation and because they may be most susceptible to negative effects of despair. Current projections estimate that the brunt of climate impacts such as sea level rise; more severe storms, flooding, and droughts; and associated challenges related to food security and water distribution will be felt in by mid-21st century [12], when current adolescents and children will become voters, scientists, industry leaders, and policy makers. Accordingly, understanding how to unite future generations in climate action is critical to equipping future leaders to meet the challenges they will face, and special attention should be paid to how to avoid the counterproductive effects of despair. Children and adolescents experience lower levels of perceived and actual control over their individual and collective actions than adults, which can make younger audiences particularly likely to experience despair in the face of climate change [13]. Though many young people are interested in global problems, feelings of helplessness, hopelessness, and pessimism are common [14-16], including 27\% of Australian adolescents that believe the "world will end before they grow old" [17]. Given the critical role adolescents will play in shaping our response to climate change impacts and their susceptibility to negative emotions related to climate change, striking a balance between building concern and avoiding despair may be particularly key with this audience.

Understanding how younger audiences build and maintain hope around climate change may be critical to finding this balance. Snyder et al. [18] conceptualize hope as a combination of agency (ability, for oneself or others, to participate in solutions) and pathways (something can be done) thinking. These two aspects of hope may serve to counteract despair because they specifically address its sources: feelings that there are no adequate solutions for climate change challenges and that individuals cannot make a difference [9,11]. Ojala [16] found that young people displayed hope by putting trust in actions of politicians and researchers as well as expressed faith in their own and other citizens' ability to affect change. Ojala's $[13,15,16,19,20]$ extensive work on climate change hope among Swedish adolescents strongly suggests that hope is a critical part of fostering climate action among younger generations. Insights from this research support the logical supposition that hope may work to overcome despair and provide a more productive response to concern, however, to our knowledge, these questions have not been empirically addressed.

Understanding the relative importance of climate change hope, concern, and despair among adolescents may provide a pathway to improving efforts to build climate action among future generations. If climate change hope can moderate how climate change concern and despair relate to behavior, interventions designed to build climate change hope could allow for communication of the complex and pressing challenges of climate change while avoiding the despair and hopelessness that breeds inaction. We began to address how climate change hope, concern and despair may interact to predict pro-environmental behavior with a case study in North Carolina, USA. Because climate concern predicted pro-environmental behavior among adults [3,6] and climate change hope predicted pro-environmental behavior among adolescents in Sweden [20], we hypothesized we would find similar relationships in our sample. Similarly, because despair breeds inaction [9], we 
expected a negative relationships between climate change despair and behavior. We also predicted that we would find interactions between climate change hope and concern and despair such that the positive relationship between climate change concern and behavior will be stronger and the negative relationship between climate change despair and behavior would be weaker among individuals with higher levels of climate change hope.

\section{Materials and Methods}

\subsection{Sampling}

We sampled in three stages for this study-schools, teachers, and students. First, we compiled a list of all 770 public middle schools in North Carolina from the North Carolina Department of Public Instruction. We then randomly selected 85 of these schools, visited each school website, and compiled a list of all science teachers that taught at those schools $(n=377)$. We then randomly selected 205 of the 377 teachers to recruit for the study. Of these teachers, 58 responded and 30 consented to participate. Each participating teacher was asked to include at least one of his/her science classes in the study. The average number of students/teacher was 60, representing a range from 5 to 123 students per teacher. In January 2014, we sent all participating teachers surveys, answer sheets, and administration instructions by mail. We requested teachers return surveys within two weeks of receiving them, and sent weekly reminders for one month after the deadline. Six of the participating teachers did not return the surveys, citing lack of time. Our final sample included 205 sixth graders, 432 seventh graders, and 835 eighth graders with the majority spanning ages 11-14 (28 students were 15 years old). The majority of the students in this sample were female $(53.3 \%)$, and white $(62.9 \%)$ with fewer African American (10.7\%), Hispanic (10.2\%), American Indian (1.3\%) and Asian (2.2\%) students. Some also identified as multi-racial $(9.0 \%)$ or other $(3.8 \%)$. Most $(66.2 \%)$ of students attended a Title I school. Title I status is a common measure of school-level socioeconomic status as these schools receive additional federal funding based on high percentages of low-income students [21].

\subsection{Instrument Development}

Because few published studies have directly addressed the variables of interest among adolescents, we combined individual items from surveys for adolescents and adapted scales designed for adults. For climate change concern, we drew questions from one of the only large-scale surveys designed for this age group [22]. The resulting four-item scale has been successfully used in previous studies with both adolescents and young adults [4,23] For climate change hope, we drew on both the Snyder et al. [24] Will and Ways Hope scale and a climate change hope scale [25]. To measure pro-environmental behavior, we adapted items from several instruments measuring pro-environmental behavior of children and adolescents $[20,26]$. To measure Title I status, we referred to data available through the National Center for Education Statistics [27].

Because we adapted several scales and generated new items, we conducted several rounds of pretesting. First, we administered the draft instrument to 27 seventh grade students and 33 eighth grade students. We asked students to circle questions that were difficult to understand and make notes on how to make improvements. Additionally, we completed cognitive interviews [28] with five students to gather general feedback and suggestions for improvement in item wording and clarity as well as assessing construct validity (e.g., what does this question make you think of?).

In addition to the qualitative pretesting of the scales, we tested each for reliability and validity. We used Cronbach's alpha to measure internal reliability, or the degree to which items within the scale measure the same construct [29]. In general, alpha scores reaching 0.7 and above are considered acceptable, 0.8 and above considered good, and 0.9 and above are excellent [29]. Cronbach's alpha measurements indicated acceptable for the climate change hope scale $(\alpha=0.75)$ and the behavior scale $(\alpha=0.78)$. The alpha for climate concern and despair were lower than ideal $(\alpha=0.67$ and 0.55 , respectively), but on par with other measures of climate concern $[4,23]$ and general risk 
perception [30]. In addition, we performed a post-hoc analysis of reliability through Cronbach's alpha (see results). We also completed a post-hoc principal confirmatory analysis (PCA) for each scale. In the case of the climate change concern scale, this analysis was confirmatory as the scale has been used in previous studies $[4,23]$. Factor analyses for the climate change hope and behavior scales were exploratory as these scales were developed for this study. We used the rule of thumb of eigenvalues greater than 1 to determine the number of factors for each of these scales [31].

\subsection{Data Analysis}

We compared the proportion of students attending a Title I school in our sample to the student population using data available through the National Center for Education Statistics and found the sample underrepresented students attending schools with Title I status $(64.6 \%$ in our sample vs. $74.7 \%$ in NC; $t=-6.91 ; p<0.001)$. We weighted our sample to adjust for this difference.

We used multiple linear regression to test how climate change hope, concern, and despair predict pro-environmental behavior individually and together while controlling for Title I status. First, we tested for independent effects of each variable by regression climate change hope, concern, and despair on behavior in model one. To tests for moderating effects of climate change hope on concern and despair, we created two interaction terms (hope ${ }^{*}$ concern and hope ${ }^{*}$ despair). In addition to all variables included in model one, we added each of these interaction terms separately in models two and three and together in model four. We also included a random effect for teacher in each model, to account for the possibility that students in the same class may have similar perceptions of climate change as they come from similar communities and have had a similar instruction with regard to climate change at school. We also included gender and ethnicity as control variables in each model as each have predicted climate change concern among adults and adolescents [4,32], but neither were significant predictors in any of the models, so we excluded them in the final models. However, because few studies have addressed how demographic variables are related to climate change perceptions among adolescents, we did test for differences in climate change hope, concern and despair between boys and girls and White and non-White students using two-side $t$-tests.

\section{Results}

Average scores on the climate change hope and concern scales suggested students in the sample were both hopeful (mean $=35.1$ out of a possible $56, \mathrm{SD}=8.4$ ) and concerned (mean $=9.9$ out of a possible $17, \mathrm{SD}=3.0$ ) about climate change and had lower levels of despair (mean $=14.3$ out of possible $28, \mathrm{SD}=8.5$ ). On average, students scored 27.2 out of a possible 50 on the behavior scale (SD $=6.7$ ). Cronbach's alpha scores were similar to the reliability measurements in pretesting (climate change hope $\alpha=0.80$, climate change despair $\alpha=0.59$, climate change concern $\alpha=0.56$, and pro-environmental behavior $\alpha=0.74)$. Although alpha levels for climate change concern and despair are lower than ideal, they approach the range of acceptability for exploratory studies [33].

Confirmatory factor analysis on the climate change concern scale confirmed one factor, and exploratory analysis revealed one factor on the climate change hope and despair scales and three factors on the behavior scale. On the concern scale, each item had a factor loading of 0.58 or greater, which is well within the range of acceptability [31]. On the climate change hope scale, we found support for one factor, with all factors above 0.42 , which is in the acceptable range for social science research [34] (Table 1). Similarly, PCA results supported a single-factor climate change despair scale, and with all factor loadings 0.65 or greater (Table 2). Exploratory factor analysis for the behavior scale revealed three factors. The first included items associated with household behavior such as turning off lights and closing the refrigerator door. The second factor included three items addressing information-seeking behavior (e.g., asking others about what to do about environmental problems), and the third factor included two items addressing transportation choice (e.g., walking for transportation) (Table 3). 
Climate change hope, concern, and despair were independently related to pro-environmental behavior in hypothesized directions (Table 4), but we did not detect interactions between climate change hope and concern or despair when placed in the model separately ( $p=0.33$ and 0.14 , respectively) or together ( $p=0.31$ and 0.14 , respectively). Standardized coefficients suggest climate change hope has the strongest relationship with behavior, followed by concern and despair (Table 4). Though we originally included student gender and ethnicity in the regression model, Title I status of schools was the only significant predictor of pro-environmental behaviors when controlling for climate change hope, concern, and despair. However, two-sided t-tests revealed that girls had higher levels of climate change concern than boys (mean $=10.3, \mathrm{SD}=2.8$ for girls vs. mean $=9.4, \mathrm{SD}=3.1$ for boys; $t=-5.9131, p<0.001$ ) as well as higher levels of hope (mean $=34.7, \mathrm{SD}=9.16$ for girls $v$ s. mean $=35.7, \mathrm{SD}=07.6$ for boys; $t=-2.27, p=0.023$ ). We found no differences in despair between boys and girls and no differences in any of the variables between White and non-White students. We found no difference in climate change hope, concern or despair based on Title I status using t-tests, but students attending Title I schools reported lower frequencies of participation in pro-environmental behaviors than students at non-Title I schools (Table 4).

Table 1. Item factor loadings for the climate change hope scale $(n=1486, \alpha=0.80)$.

\begin{tabular}{lccc}
\hline \multicolumn{1}{c}{ Item } & Mean & SD Factor Loadings \\
\hline I believe people will be able to stop global warming. & 3.94 & 1.70 & 0.58 \\
\hline $\begin{array}{l}\text { I believe scientists will be able to find ways to solve problems caused by } \\
\text { climate change. }\end{array}$ & 4.93 & 1.61 & 0.71 \\
\hline $\begin{array}{l}\text { Even when some people give up, I know there will be people who will } \\
\text { continue to try to solve problems caused by climate change. }\end{array}$ & 5.42 & 1.62 & 0.65 \\
\hline $\begin{array}{l}\text { Because people can learn from our mistakes, we will influence climate } \\
\text { change in a positive direction. }\end{array}$ & 4.41 & 1.65 & 0.68 \\
\hline $\begin{array}{l}\text { Every day, more people care about problems caused by climate change. } \\
\text { If everyone works together, we can solve problems caused by }\end{array}$ & 4.99 & 1.58 & 0.58 \\
\hline $\begin{array}{l}\text { climate change. } \\
\begin{array}{l}\text { At the present time, I am energetically pursuing ways to solve problems } \\
\text { caused by climate change. }\end{array}\end{array}$ & 3.11 & 1.75 & 0.77 \\
\hline $\begin{array}{l}\text { I know that there are many things that I can do to help solve problems } \\
\text { caused by climate change. }\end{array}$ & 4.43 & 1.70 & 0.43 \\
\hline
\end{tabular}

Each item associated with a 7-point Likert scale ranging from (1) strongly disagree to (7) agree, with an additional choice of "I do not see climate change as a problem". Respondents who chose "I do not see climate change as a problem) were excluded from analysis.

Table 2. Item factor loadings for the climate change despair scale $(n=1486, \alpha=0.59)$.

\begin{tabular}{lccc}
\hline \multicolumn{1}{c}{ Item } & Mean & SD & Factor Loadings \\
\hline $\begin{array}{l}\text { I feel helpless to solve problems caused by climate change. } \\
\begin{array}{l}\text { The actions I can take are too small to help solve problems } \\
\text { caused by climate change. }\end{array}\end{array}$ & 4.57 & 1.66 & 0.65 \\
\hline $\begin{array}{l}\text { Problems caused by climate change are out of my control. } \\
\text { Climate change is such a complex problem, we will never be } \\
\text { able to solve it. }\end{array}$ & 4.97 & 1.77 & 0.69 \\
\hline
\end{tabular}

Each item associated with a 7-point Likert scale ranging from (1) strongly disagree to (7) agree, with an additional choice of "I do not see climate change as a problem". Respondents who chose "I do not see climate change as a problem) were excluded from analysis. 
Table 3. Item factor loadings for the pro-environmental behavior scale $(\mathrm{n}=1486, \alpha=0.74)$.

\begin{tabular}{|c|c|c|c|c|c|}
\hline Item & Mean & SD & $\begin{array}{c}\text { Household } \\
\text { Behavior } \alpha=0.69\end{array}$ & $\begin{array}{c}\text { Information } \\
\text { Seeking } \alpha=0.66\end{array}$ & $\begin{array}{c}\text { Transportation } \\
\alpha=0.64\end{array}$ \\
\hline $\begin{array}{l}\text { Turn off the lights at home when } \\
\text { they are not in use }\end{array}$ & 4.04 & 1.00 & 0.60 & & \\
\hline $\begin{array}{l}\text { Ask my family to recycle some } \\
\text { of the things we use }\end{array}$ & 2.85 & 1.38 & 0.79 & & \\
\hline $\begin{array}{l}\text { Ask other people to turn off the } \\
\text { water when it is not in use }\end{array}$ & 3.23 & 1.40 & 0.52 & & \\
\hline $\begin{array}{l}\text { Close the refrigerator door while } \\
\text { I decide what to get out of it }\end{array}$ & 3.04 & 1.51 & 0.39 & & \\
\hline Recycle at home & 3.27 & 1.51 & 0.78 & & \\
\hline $\begin{array}{l}\text { Choose and environmental topic } \\
\text { when I can choose a topic for an } \\
\text { assignment in school }\end{array}$ & 2.32 & 0.94 & & 0.66 & \\
\hline $\begin{array}{l}\text { Talk with my parents about how } \\
\text { to do something about } \\
\text { environmental problems }\end{array}$ & 1.97 & 1.03 & & 0.77 & \\
\hline $\begin{array}{l}\text { Ask others about things I can do } \\
\text { about environmental problems }\end{array}$ & 1.80 & 0.93 & & 0.78 & \\
\hline Walk for transportation & 2.45 & 1.09 & & & 0.83 \\
\hline Bike for transportation & 2.19 & 1.12 & & & 0.85 \\
\hline
\end{tabular}

Each item associated with a 5-point frequency Likert scale ranging from (1) never to (5) always.

Table 4. Predictors of climate-related pro-environmental behavior among middle school students.

\begin{tabular}{cccc}
\hline Variable & Beta & Std. Beta & $p$ \\
\hline Climate change hope & 0.24 & 0.30 & $<0.001$ \\
Climate change concern & 0.50 & 0.22 & $<0.001$ \\
Climate change despair & -0.12 & -0.08 & $<0.001$ \\
Title I & -2.39 & -0.17 & $<0.001$ \\
Constant & 17.12 & & \\
\hline
\end{tabular}

Model includes random effect for teacher and is weighted to adjust for differences between the sample and state averages for Title I status.

\section{Discussion}

Climate change hope appears to be a key predictor of pro-environmental behavior in its own right. The positive relationship between climate change hope and behavior is consistent with previous research suggesting that climate change hope is an antecedent to engagement with climate change solutions $[13,20]$. Intuitively, we would expect climate change hope to encourage action because it provides resiliency to the paralyzing effects of despair [9]. If this were the main function of climate change hope, however, an interaction between climate change hope and despair should exist because hope would guard against despair. Similarly, we would expect an interaction with climate change concern because hope would allow for a more productive response to elevated concern (i.e., action instead of despair). Among adolescents, our results seem to suggest that climate change hope may operate more to provide motivation rather than resiliency. Snyder et al.'s [18] understanding of hope provides support for this finding, as hope incorporates pathways (seeing a route to a solution) and agency thinking (belief in one's ability to make a difference), which interact to motivate action. As our measure of climate change hope included agency and pathways thinking, our results may highlight how communicating concrete things that adolescents can do to address climate change (i.e., pathways) as well as that their actions make a difference (i.e., agency) may lead to more pro-environmental behavior. 
In addition to the importance of climate change hope as a motivational factor, our results suggest that adolescents respond to climate change concern not with inaction, but with pro-environmental behavior. Several studies have found a positive link between concern over climate change and pro-environmental behavior among both adults [3,5,6] and children [20,35]. Within the realm of political psychology, anxiety and worry are linked to deliberation and critical thinking [36], in which individuals take time to cognitively appraise the situation and decide how to move forward [37]. Because worry is an unpleasant emotion, individuals seek to move past these feelings by finding ways to engage in solutions [16,37]. For instance, Swedish young people concerned about climate change acted by buying eco-labeled products, cycling to school, and conserving house-hold energy [37]. The positive relationships between climate change concern and pro-environmental behavior in our study is consistent with these findings, suggesting that fostering concern for climate change may encourage action among adolescents.

Although climate change despair was the least important predictor of pro-environmental behavior in our study, the negative relationship supports research suggesting that attending to feelings of despair should be a part of climate literacy efforts among K-12 audiences. Several studies have documented feelings of climate change despair among adolescents $[17,38]$ and our research suggests that these feelings can lead to inaction as among they do among adults [9]. Although we expected that climate change hope would mitigate the impact of despair, the lack of interaction between climate change hope and despair suggests that despair should be addressed directly rather than being treated as a lower level of hope. Several researchers suggest that climate literacy efforts should work to build hope to overcome despair [9,39]. Such efforts may be merited because hope predicts behavior, but directly acknowledging and addressing feelings of despair may also be an important part of avoiding the inaction among adolescents [16].

Although our results do find independent positive relationships between both climate change concern and hope and pro-environmental behavior, future studies should examine how each of these factors relate to pro-environmental behavior over time. Ojala [16,37] proposes three types of coping strategies employed by young people when considering climate change: emotion-focused, problem-focused, and meaning-focused. Emotion-focused coping involves distancing oneself from unpleasant feelings of worry or anxiety by downplaying the seriousness of climate change, which is consistent with the effects of fear-based climate change messaging among adults [9,39]. Problem-focused coping involves trying to do something to address climate change, which can lead to action $[6,20]$. However, because climate change is a bigger problem than young people can address individually, relying solely on problem-focused coping strategies may lead to lower senses of wellbeing $[19,37]$. Meaning-focused coping is most aligned with hope and involves recognizing the negative aspects of climate change but focusing on positive trends (e.g., climbing societal climate change acceptance) and placing trust in societal actors (e.g., United Nations conference on climate change) $[37,40]$. It is possible that our results highlight the role of both problem-focused coping (action inspired directly by concern) and meaning-focused coping (action motived by hope). Because this study is observational, we were not able to examine how climate change concern and hope may relate to behavior over time, although the slightly stronger relationship with climate change hope and behavior may hint that hope is a more important motivational force than climate change concern on its own.

Our results associated with student demographics suggest that gender may factor into building climate concern and that special attention should be paid to students from lower socioeconomic backgrounds when fostering pro-environmental behavior. Previous research suggests women and girls exhibit higher levels of climate change concern [4,32] and pro-environmental behavior [20,41]. These differences are attributed to higher appraisals of risk in general [42] and higher instances of biospheric values [43] among women. We also found that girls had higher levels of climate change hope than boys, which to our knowledge is a new contribution. One Swedish study did investigate gender differences associated with "constructive hope" but found no difference [13]. Additionally, 
students attending Title I schools were less likely to engage in pro-environmental behavior regardless of climate change hope and concern levels, consistent with other studies linking low socio-economic status with low levels of pro-environmental behavior [44-46]. This trend may be explained by "post-material values", in which individuals become concerned with the environment only as they are able to attend to aesthetic needs, which increases with affluence [47]. Although some have critiqued this view as overly simplistic [48,49], our results do suggest that special efforts should be made to encourage pro-environmental behavior among students of low socio-economic status. As less affluent communities often experience greater exposure to environmental impacts [50], education efforts incorporating environmental justice concepts may encourage "grassroots environmentalism", which focuses on community action among socioeconomically disadvantaged populations $[49,51,52]$.

\section{Conclusions}

Understanding how to encourage younger generations to engage in solutions related to climate change is critical to ensuring appropriate societal responses to the climate impacts that are projected in the mid-21st century [12]. Our results are consistent with emerging work on climate change hope among adolescents $[13,16,19,20,37]$ by highlighting how hope may foster environmental stewardship. Climate literacy efforts designed for adolescents should include activities that explicitly acknowledge feelings of despair and build agency and pathways thinking; such as highlighting societal progress in addressing climate change, providing concrete ways that adolescents can engage in climate change solutions, and emphasizing that collective action does make a difference. Avoiding despair is important [39], however climate literacy efforts should not shy away from communicating the seriousness of climate change as adolescents are likely capable of productively responding to concern. Climate literacy efforts should also take into account how diverse groups of students may approach climate change differently. Activities highlighting environmental justice success stories may be particularly helpful in reaching students from disadvantaged socioeconomic backgrounds. Future studies should explore how curricula may be effective at building climate change concern and hope, and how these variables may impact behavior over time.

Acknowledgments: We would like to thank Christine Li and Martha Monroe at University of Florida for their valuable insights and project and Howard Bondell at NC State University for help with analysis. We also thank our funders, NC Sea Grant (Project ID \# 6411).

Author Contributions: Kathryn Stevenson and Nils Peterson conceived and designed the experiments; Kathryn Stevenson performed the experiments; Kathryn Stevenson and Nils Peterson analyzed the data; Kathryn Stevenson wrote the paper.

Conflicts of Interest: The authors declare no conflict of interest.

\section{References}

1. Lazo, J.K.; Kinnell, J.C.; Fisher, A. Expert and Layperson Perceptions of Ecosystem Risk. Risk Anal. 2000, 20, 179-194. [CrossRef] [PubMed]

2. Sundblad, E.-L.; Biel, A.; Gärling, T. Cognitive and affective risk judgements related to climate change. J. Environ. Psychol. 2007, 27, 97-106. [CrossRef]

3. Tobler, C.; Visschers, V.H.M.; Siegrist, M. Consumers' knowledge about climate change. Clim. Chang. 2012, 114, 189-209. [CrossRef]

4. Stevenson, K.T.; Peterson, M.N.; Bondell, H.D.; Moore, S.E.; Carrier, S.J. Overcoming skepticism with education: Interacting influences of worldview and climate change knowledge on perceived climate change risk among adolescents. Clim. Chang. 2014, 126, 293-304. [CrossRef]

5. Alhakami, A.S.; Slovic, P. A psychological study of the inverse relationship between perceived risk and perceived benefit. Risk Anal. 1994, 14, 1085-1096. [CrossRef] [PubMed]

6. Smith, N.; Leiserowitz, A. The Role of Emotion in Global Warming Policy Support and Opposition. Risk Anal. 2014, 34, 937-948. [CrossRef] [PubMed] 
7. Smith, N.; Leiserowitz, A. The rise of global warming skepticism: Exploring affective image associations in the United States over time. Risk Anal. 2012, 32, 1021-1032. [CrossRef] [PubMed]

8. Witte, K.; Allen, M. A Meta-Analysis of Fear Appeals: Implications for Effective Public Health Campaigns. Health Educ. Behav. 2000, 27, 591-615. [CrossRef] [PubMed]

9. Stern, P.C. Psychology: Fear and hope in climate messages. Nat. Clim. Chang. 2012, 2, 572-573. [CrossRef]

10. Leiserowitz, A. The Day After Tomorrow: A Study of Climate Change Risk Perception. Environment 2004, 46, 22-39. [CrossRef]

11. Van Zomeren, M.; Spears, R.; Wayne, C. Experimental evidence for a dual pathway model analysis of coping with the climate crisis. J. Environ. Psychol. 2010, 30, 339-346. [CrossRef]

12. IPCC. Climate Change 2014: Synthesis Report-Contribution of Working Groups I, II, and III to the Fifth Assessment Report of the Intergovernmental Panel on Climate Change. 2014. Available online: http:/ / www.ipcc.ch/report/ar5/syr/ (accessed on 21 December 2015).

13. Ojala, M. Hope in the Face of Climate Change: Associations With Environmental Engagement and Student Perceptions of Teachers' Emotion Communication Style and Future Orientation. J. Environ. Educ. 2015, 46, 133-148. [CrossRef]

14. Corner, A. Psychology: Science literacy and climate views. Nat. Clim. Chang. 2012, 2, 710-711. [CrossRef]

15. Ojala, M. Climate change skepticism among adolescents. J. Youth Stud. 2015, 18, 1135-1153. [CrossRef]

16. Ojala, M. Regulating worry, promoting hope: How do children, adolescents, and young adults cope with climate change? Int. J. Environ. Sci. Educ. 2012, 7, 537-561.

17. Tucci, J.; Mitchell, J.; Goddard, C. Children's Fears, Hopes and Heroes: Modern Childhood in Australia. 2007. Available online: http://www.childhood.org.au/ /media/Files/Research/Childrens fears hopes and heroes.ashx (accessed on 21 December 2015).

18. Snyder, C.; Rand, K.L.; Sigmon, D.R. Hope theory: A member of the positive psychology family. In Handbook of Positive Psychology; Snyder, C., Lopez, S., Eds.; Oxford University Press: Cary, NC, USA, 2005.

19. Ojala, M. Coping with Climate Change among Adolescents: Implications for Subjective Well-Being and Environmental Engagement. Sustainability 2013, 5, 2191-2209. [CrossRef]

20. Ojala, M. Hope and climate change: The importance of hope for environmental engagement among young people. Environ. Educ. Res. 2012, 18, 625-642. [CrossRef]

21. 107th Congress. Public Law 107-110-No Child Left Behind (NCLB) Act of 2001. 2002. Available online: http://www2.ed.gov/policy/elsec/leg/esea02/107-110.pdf (accessed on 21 December 2015).

22. Leiserowitz, A.; Smith, N.; Marlon, J. American Teens' Knowledge of Climate Change. 2011. Available online: http:/ / environment.yale.edu/uploads/american-teens-knowledge-of-climate-change.pdf (accessed on 21 December 2015).

23. Stevenson, K.T.; Lashley, M.A.; Chitwood, M.; Peterson, M.N.; Moorman, C.E. How emotion trumps logic in climate change risk perception: Exploring the affective heuristic among wildlife science students. Hum. Dimens. Wildl. 2015, 20, 501-513. [CrossRef]

24. Snyder, C.R.; Harris, C.; Anderson, J.R.; Holleran, S.A.; Irving, L.M.; Sigmon, S.T.; Yoshinobu, L.; Gibb, J.; Langelle, C.; Harney, P. The will and the ways: Development and validation of an individual-differences measure of hope. J. Pers. Soc. Psychol. 1991, 60, 570-585. [CrossRef] [PubMed]

25. Li, C.J.; Monroe, M.C. Understanding, Measuring and Cultivating Hope about Climate Change among High School Students. 2015. unpublished work.

26. McBeth, B.; Hungerford, H.; Marcinkowski, T.; Volk, T.; Cifranick, K. National Environmental Literacy Assessment, Phase Two: Measuring the Effectiveness of North American Environmental Education Programs with Respect to the Parameters of Environmental Literacy-Final Research Report. 2011. Available online: https://www.naaee.net/sites/default/files/programs/research/NELA_Phase_II_ Report.pdf (accessed on 21 December 2015).

27. National Center for Education Statistics (NCES). US Department of Education. Available online: http://nces.ed.gov/ (accessed on 18 March 2013).

28. Desimone, L.M.; Le Floch, K.C. Are We Asking the Right Questions? Using Cognitive Interviews to Improve Surveys in Education Research. Educ. Eval. Policy Anal. 2004, 26, 1-22. [CrossRef]

29. Gliem, J.A.; Gliem, R.R. Calculating, Interpreting, and Reporting Cronbach's Alpha Reliability Coefficient for Likert-Type Scales. In Proceedings of Midwest Research to Practice Conference in Adult, Continuing, and Community Education, Columbus, OH, USA, 8-10 October 2003. 
30. Betz, N.E.; Weber, E.U. A Domain-specific Risk-attitude Scale: Measuring Risk Perceptions and Risk Behaviors. J. Behav. Decis. Mak. 2002, 290, 263-290.

31. Williams, B.; Brown, T.; Onsman, A. Exploratory factor analysis: A five-step guide for novices. Aust. J. Paramadicine 2012, 8, 1-13.

32. McCright, A.M. The effects of gender on climate change knowledge and concern in the American public. Popul. Environ. 2010, 32, 66-87. [CrossRef]

33. Hair, J.H.; Black, W.C.; Babin, B.J.; Anderson, R.E. Multivariate Data Analysis, 7th ed.; Prentice Hall: Upper Saddle River, NJ, USA, 2010.

34. Costello, A.B.; Osborne, J.W. Best practices in exploratory factor analysis: Four recommendations for getting the most from your analysis. Pract. Assess. Res. Eval. 1994, 10, 27-29.

35. Taber, F.; Taylor, N. Climate of Concern-A Search for Effective Strategies for Teaching Children about Global Warming. Int. J. Environ. Sci. Educ. 2009, 4, 97-116.

36. Valentino, N.A.; Hutchings, V.L.; Banks, A.J.; Davis, A.K. Is a worried citizen a good citizen? Emotions, political information seeking, and learning via the Internet. Polit. Psychol. 2008, 29, 247-273. [CrossRef]

37. Ojala, M. Young people and global climate change: Emotions, coping and engagement in everyday life. In Geographies of Children and Young People Handbook; Skelton, T., Ansell, N., Kocker, N., Eds.; Springer: Berlin, Germany, 2016; in press.

38. Corner, A.; Roberts, O.; Chiari, S.; Völler, S.; Mayrhuber, E.S.; Mandl, S.; Monson, K. How do young people engage with climate change? The role of knowledge, values, message framing, and trusted communicators. Wiley Interdiscip. Rev. Clim. Chang. 2015, 6, 523-534. [CrossRef]

39. Cook, J. Countering Skepticism, Denial, and Despair. In Climate Smart \& Energy Wise; Mccaffrey, M.S., Ed.; Sage: Thousand Oaks, CA, USA, 2015; pp. 110-121.

40. Folkman, S. The case for positive emotions in the stress process. Anxiety Stress Coping 2008, $21,3-14$. [CrossRef] [PubMed]

41. Kollmuss, A.; Agyeman, J. Mind the Gap: Why do people act environmentally and what are the barriers to pro-environmental behavior? Environ. Educ. Res. 2002, 8, 37-41. [CrossRef]

42. Finucane, M.L.; Slovic, P.; Mertz, C.K.; Flynn, J.; Satterfield, T.A. Gender, race, and perceived risk: The "white male" effect. Health. Risk Soc. 2000, 2, 159-172. [CrossRef]

43. Stern, P.C.; Dietz, T.; Kalof, L. Value Orientations, Gender, and Environmental Concern. Environ. Behav. 1993, 25, 322-348. [CrossRef]

44. Stevenson, K.T.; Peterson, M.N.; Bondell, H.D.; Mertig, A.G.; Moore, S.E. Environmental, institutional, and demographic predictors of environmental literacy among middle school children. PLoS ONE 2013. [CrossRef] [PubMed]

45. Straughan, R.D.; Roberts, J.A. Environmental segmentation alternatives: A look at green consumer behavior in the new millennium. J. Consum. Mark. 1999, 16, 558-575. [CrossRef]

46. Steg, L.; Dreijerink, L.; Abrahamse, W. Factors influencing the acceptability of energy policies: A test of VBN theory. J. Environ. Psychol. 2005, 25, 415-425. [CrossRef]

47. Inglehart, R. PS: Political Science and Politics. PS Polit. Sci. Polit. 1995, 28, 57-72. [CrossRef]

48. Xiao, C.; Dunlap, R.E. Validating a Comprehensive Model of Environmental Concern Cross-Nationally: A U.S.-Canadian Comparison*. Soc. Sci. Q. 2007, 88, 471-493. [CrossRef]

49. Chen, X.; Peterson, M.N.; Hull, V.; Lu, C.; Hong, D.; Liu, J. How perceived exposure to environmental harm influences environmental behavior in urban China. Ambio 2013, 42, 52-60. [CrossRef] [PubMed]

50. Bullard, R.D. Dumping in Dixie: Race, Class, and Environmental Quality; Westview: Boulder, CO, USA, 1990.

51. Pampel, F.C.; Hunter, L.M. Cohort Change, Diffusion, and Support for Environmental Spending in the United States. AJS 2012, 118, 420-448. [PubMed]

52. Dunlap, R.E.; Mertig, A.G. Global Concern for the Environment: Is Affluence a Prerequisite? J. Soc. Issues 1995, 51, 121-137. [CrossRef]

(C) 2015 by the authors; licensee MDPI, Basel, Switzerland. This article is an open access article distributed under the terms and conditions of the Creative Commons by Attribution (CC-BY) license (http://creativecommons.org/licenses/by/4.0/). 